\title{
COASTAL VULNERABILITY ANALYSIS IN PADANG PARIAMAN REGENCY, WEST SUMATERA
}

\author{
Fauzi Ramadhan ${ }^{1 *}$, Mubarak $^{2}$, Elizal $^{2}$ \\ ${ }^{1}$ Student of The Faculty of Fisheries and Marine Science University of Riau, Pekanbaru \\ ${ }^{2}$ Lecturer at The Faculty of Fisheries and Marine Science University of Riau, Pekanbaru \\ *fauzir06@gmail.com
}

\begin{abstract}
This research was conducted in June to July 2019. It aimed to analyzed the vulnerability and the shoreline change of coastal area of Padang Pariaman Regency, West Sumatera Province. Survey method with direct field observations were applied and different satellite imageries were also used to find out the shoreline change of coast under study. The results showed that there five categories of changes, namely high and low accretion $(>2.1 \mathrm{~m}$ $\left.\mathrm{yr}^{-1} ; 1-2 \mathrm{~m} \mathrm{yr}^{-1}\right)$; stable condition $\left(-1\right.$ to $\left.1 \mathrm{~m} \mathrm{yr}^{-1}\right)$; and high and low erosion $\left(<-2 \mathrm{~m} \mathrm{yr}^{-1} ;-1\right.$ to $\left.-2 \mathrm{~m} \mathrm{yr}^{-1}\right)$. Furthermore, the percentages of coastal vulnerability of the areas under study can be classified into five categories such as Very Low Condition (17.27 \%), Low Condition (39.68 \%), Medium Condition (29.02 \%), High Condition (8.88 \%), and Very High Condition $(5,75 \%)$. In addition, the districts of Sungai Limau and Batang Gasan had very high vulnerability condition.
\end{abstract}

Keywords: Padang Pariaman, Shoreline, Vulnerability

\section{PENDAHULUAN}

Pesisir merupakan daerah pertemuan antara daratan dan laut, dimana kearah darat mencakup kawasan yang masih mendapat pengaruh dari laut, dan kearah laut masih mendapat pengaruh dari darat. Lebih dari $70 \%$ kota besar di dunia berada di daerah pesisir. Diperkirakan hampir $60 \%$ dari total populasi penduduk Indonesia berada di wilayah pesisir (Baransano, 2011).Kerentanan pesisir merupakan kecendrungan suatu kawasan pesisir dalam mengalami kerusakan. Penelitian mengenai kerentanan pesisir sudah banyak dilakukan seperti pantai Timur Rio De Janeiro Brazil oleh Barros dan Muehe (2010), pesisir Kota Pariaman oleh Abdillah dan Ramdhan (2012)

Haryani (2018) menyatakan rata-rata erosi di Kabupaten Padang Pariaman adalah $17,61 \mathrm{~m}$ yang terjadi pada 5 titik. erosi pantai ini juga sudah merusak beberapa rumah nelayan di beberapa desa. Selain erosi pantai Kabupaten Padang Pariaman juga memiliki kerentanan yang tinggi terhadap bencana tsunami. Kabupaten Padang Pariaman merupakan peringkat ke 35 dari 249 Kabupaten/Kota dalam indeks risiko bencana tsunami di Indonesia dan secara keseluruhan kawasan pesisir Kabupaten Padang Pariaman berada dalam kelas bahaya tinggi untuk resiko tsunami (BNPB, 2013). Penelitian mengenai kerentanan pesisir Kabupaten Padang Pariaman sangat penting dilakukan untuk mengetahui tingkat kerentanan pesisir di kawasan tersebut.

\section{METODE PENELITIAN}

Penelitian ini mencakup 5 Kecamatan di pesisir Kabupaten Padang Pariaman. 
Penelitian dilakukan dari bulan Juni - Juli 2019. Proses pengambilan data lapangan dilakukan pada bulan Juni 2019 dengan cara purposive sampling. Metode penelitian yang digunakan adalah metode survey. Penelitian dibagi kedalam tiga tahapan yaitu pengumpulan data variabel fisik pesisir, pengolahan data, dan analisis kerentanan pesisir. Pemetaan kerentanan pesisir dilakukan menggunakan metode smartline pada daerah sejajar pantai dan tegak lurus pantai.

\section{Pengumpulan Data}

Variabel fisik pesisir yang digunakan dalam penilaian kerentanan pesisir Kabupaten Padang Pariaman meliputi 10 data primer dan 4 data sekunder (Tabel 1). Material penyusun pantai, geomorfologi pantai, paparan terhadap gelombang, fitur berm, fitur beachface, tata guna lahan dan kondisi pelindung pantai diperoleh dengan cara pengamatan langsung di lapangan. Kemiringan pantai diukur menggunakan kompas. Ukuran butir diukur menggunakan skala wenworth. Jarak antara garis pantai dengan objek yang rentan diukur menggunakan roll meter.

Tabel 1. Parameter fisik kerentanan pesisir

\begin{tabular}{|c|c|c|c|c|c|c|c|}
\hline No. & Parameter & Sumber & $\begin{array}{l}\text { Sangat } \\
\text { rendah }\end{array}$ & Rendah & Sedang & Tinggi & Sangat tinggi \\
\hline & & & 1 & 2 & 3 & 4 & 5 \\
\hline 1 & $\begin{array}{l}\text { Material penyusun } \\
\text { pantai }\end{array}$ & $\begin{array}{l}\text { Sharples } \\
\text { al., } 2009\end{array}$ & Ice & Coral & Hard rock & Soft rock & Soft sedimen \\
\hline 2 & Geomorfologi & $\begin{array}{l}\text { Jadidi et. al., } \\
2013\end{array}$ & Tebing & $\begin{array}{l}\text { Talus, stable } \\
\text { beach with } \\
\text { vegetation }\end{array}$ & $\begin{array}{l}\text { Talus, stable } \\
\text { beach without } \\
\text { vegetation }\end{array}$ & Beach & $\begin{array}{l}\text { Delta, rawa, } \\
\text { dune (gundukan } \\
\text { pasir) }\end{array}$ \\
\hline 3 & Elevasi/ketinggian (m) & $\begin{array}{l}\text { Jadidi et. al., } \\
2013\end{array}$ & $>25$ & $17-24$ & $11-17$ & $4-10$ & $0-3$ \\
\hline 4 & $\begin{array}{ll}\text { Paparan } & \text { terhadap } \\
\text { gelombang } & \end{array}$ & $\begin{array}{l}\text { Aboudha \& } \\
\text { woodroffe, } \\
2010\end{array}$ & & Terlindung & $\begin{array}{l}\text { Terlindung } \\
\text { sebagian }\end{array}$ & Terpapar & $\begin{array}{l}\text { Terpapar } \\
\text { sepenuhnya }\end{array}$ \\
\hline 5 & Slope/kemiringan (\%) & $\begin{array}{l}\text { Jadidi et. al., } \\
2013\end{array}$ & $1-13$ & $14-20$ & $21-28$ & $29-35$ & $>36$ \\
\hline 6 & $\begin{array}{l}\text { Tinggi gelombang } \\
\text { signifikan }\end{array}$ & $\begin{array}{l}\text { Jadidi et. al., } \\
2013\end{array}$ & $<0,5$ & $0,5-1$ & $1-1,5$ & $1,5-2$ & $>2$ \\
\hline 7 & Fitur berm & $\begin{array}{l}\text { Jadidi et. al., } \\
2013\end{array}$ & $\begin{array}{l}\text { Hutan, } \\
\text { tambak, } \\
\text { rawa }\end{array}$ & $\begin{array}{l}\text { Daerah } \\
\text { pedesaan }\end{array}$ & $\begin{array}{l}\text { Mixed rural } \\
\text { zone }\end{array}$ & $\begin{array}{l}\text { Urban } \\
\text { zone }\end{array}$ & $\begin{array}{l}\text { Mixed urban } \\
\text { (industri, } \\
\text { sekolah dll) }\end{array}$ \\
\hline 8 & Ukuran butir & Wenworth & $\begin{array}{l}\text { Sangat } \\
\text { halus }\end{array}$ & Halus & Sedang & Kasar & Sangat kasar \\
\hline 9 & Tunggang pasut (m) & $\begin{array}{l}\text { Jadidi et. al., } \\
2013\end{array}$ & $<1$ & $1-1,9$ & $2-4$ & $4,1-6$ & $>6$ \\
\hline 10 & $\begin{array}{l}\text { Jarak antara garis pantai } \\
\text { dengan objek yang } \\
\text { rentan }\end{array}$ & $\begin{array}{l}\text { Jadidi et. al., } \\
2013\end{array}$ & $>61$ & $31-60$ & $21-30$ & $11-20$ & $0-10$ \\
\hline 11 & Fitur beachface & $\begin{array}{l}\text { Aboudha \& } \\
\text { woodroffe, } \\
2010\end{array}$ & $\begin{array}{l}\text { Pelindung } \\
\text { pantai }\end{array}$ & Sabuk hijau & & & Lahan kosong \\
\hline 12 & $\begin{array}{l}\text { Perubahan } \\
\text { pantai }(\mathrm{m} / \mathrm{t})\end{array}$ & $\begin{array}{l}\text { Aboudha \& } \\
\text { woodroffe, } \\
2010\end{array}$ & $\begin{array}{l}\text { Akresi } \\
(>2,1)\end{array}$ & $\begin{array}{l}\text { Stabil } \\
(1-2)\end{array}$ & $\begin{array}{l}\text { Stabil } \\
(-1-+1)\end{array}$ & $\begin{array}{l}\text { Erosi sedang } \\
(-1--2)\end{array}$ & $\begin{array}{l}\text { Erosi tinggi (<- } \\
\text { 2) }\end{array}$ \\
\hline 13 & Tata guna lahan & Ozyurt, 2007 & $\begin{array}{l}\text { Protected } \\
\text { area }\end{array}$ & Unclaimed & Settlement & Industrial & Agriculture \\
\hline 14 & $\begin{array}{l}\text { Kondisi } \\
\text { pantai }\end{array}$ & $\begin{array}{l}\text { Jadidi et. Al., } \\
2013\end{array}$ & Bagus & & $\begin{array}{l}\text { Perlu } \\
\text { perbaikan }\end{array}$ & & $\begin{array}{l}\text { Tidak ada } \\
\text { pelindung } \\
\text { pantai }\end{array}$ \\
\hline
\end{tabular}

Nilai tunggang pasut diperoleh dengan cara mencari selisih antara pasang tertinggi dengan surut terendah pada saat purnama di lokasi penelitian. Data pasut yang digunakan adalah data prediksi pasut
Kabupaten Padang Pariaman yang dikeluarkan oleh Badan Informasi Geospasial.

Nilai elevasi pantai diperoleh dengan cara mengolah citra DEM Kabupaten 
Padang Pariaman yang diunduh melalui situs https://earth https://earthexplorer.usgs.gov. Resolusi spasial yang dimiliki oleh data ini sebesar 1 arc second atau $30 \times 30 \mathrm{~m}$ dengan tahun perekaman 2011.

Laju perubahan garis pantai dihitung dengan cara membandingkan 2 garis pantai yang memiliki tahun berbeda. Perhitungan menggunakan rumus statistik EPR (End Point Rate) (Thieler et al.,2009), dengan formulasi:

$$
\begin{gathered}
E P R=\frac{\text { Jarak Antara Dua Garis Pantai }(\mathrm{m})}{\text { Rentang Tahun Kedua Garis Pantai (tahun) }} \\
\text { Data garis pantai diperoleh dengan }
\end{gathered}
$$
cara digitasi citra satelit. Citra yang digunakan dalam penelitian ini adalah landsat 5 tahun perekaman 2014 dan landsat 8 tahun perekaman 2019. Nilai tinggi gelombang signifikan diperoleh dari situs BMKG Ocean Forecast. Nilai tinggi gelombang diamati pada beberapa titik di sepanjang pesisir Kabupaten Padang Pariaman.

\section{Analisis Data}

Analisis data dilakukan menggunakan 14 variabel fisik pesisir. Perhitungan tingkat kerentanan wilayah pesisir dihitung dengan menggunakan rumus indeks kerentanan pesisir seperti yang digunakan dalam (Gornitz et al., 1991).

$$
\mathrm{CVI}=\sqrt{\left(\frac{\mathrm{X} 1 \times X 2 \times X 3 \ldots X n}{\mathrm{n}}\right)}
$$

$\mathrm{Xn}=$ Nilai Kerentanan masing-masing parameter

$\mathrm{n}=$ Jumlah parameter

Hasil perhitungan CVI selanjutnya dibagi kedalam 5 kelas untuk memperoleh indeks kerentanan pesisir Kabupaten Padang Pariaman. Klasifikasi terdiri dari kerentanan sangat rendah, rendah, sedang, tinggi dan sangat tinggi (Tabel 2).

Tabel 2. Klasifikasi CVI

\begin{tabular}{clllll}
\hline CVI & $<20 \%$ & $20 \%-40 \%$ & $40 \%-60 \%$ & $60-80 \%$ & $>80 \%$ \\
\hline Kerentanan & $\begin{array}{l}\text { Sangat } \\
\text { Rendah }\end{array}$ & Rendah & Sedang & Tinggi & $\begin{array}{c}\text { Sangat } \\
\text { Tinggi }\end{array}$ \\
\hline
\end{tabular}

Sumber : Kumar et al., 2010

\section{Hasil dan Pembahasan}

Material penyusun pantai pesisir Kabupaten Padang Pariaman adalah soft sediment dengan ukuran butir sedimen sedang. Bentuk geomorfologi adalah beach atau pantai landai berpasir. Geomorfologi pantai dengan bentuk beach memiliki tingkat kerentanan yang tinggi terhadap bencana pesisir (Jadidi et. al., 2013)

Nilai elevasi atau ketinggian pantai Kabupaten Padang Pariaman berkisar dari 0-17 meter. Elevasi yang mendominasi pesisir padang pariaman adalah elevasi sangat rendah (0-3 m), elevasi rendah (4-10 m) dan elevasi sedang (11-17 m) (Gambar 1). Elevasi pantai yang rendah akan menyebabkan meningkatnya peluang pesisir pantai tersebut mengalami erosi. Nilai elevasi yang rendah akan menyebabkan meningkatnya frekuensi banjir dan luasan genangan di wilayah pesisir yang berakibat erosi, hilangnya lahan kering terutama jika genangan bersifat permanen dan intrusi air laut kearah darat sehingga menurunkan kualitas air tanah sebagai sumber air tawar. 


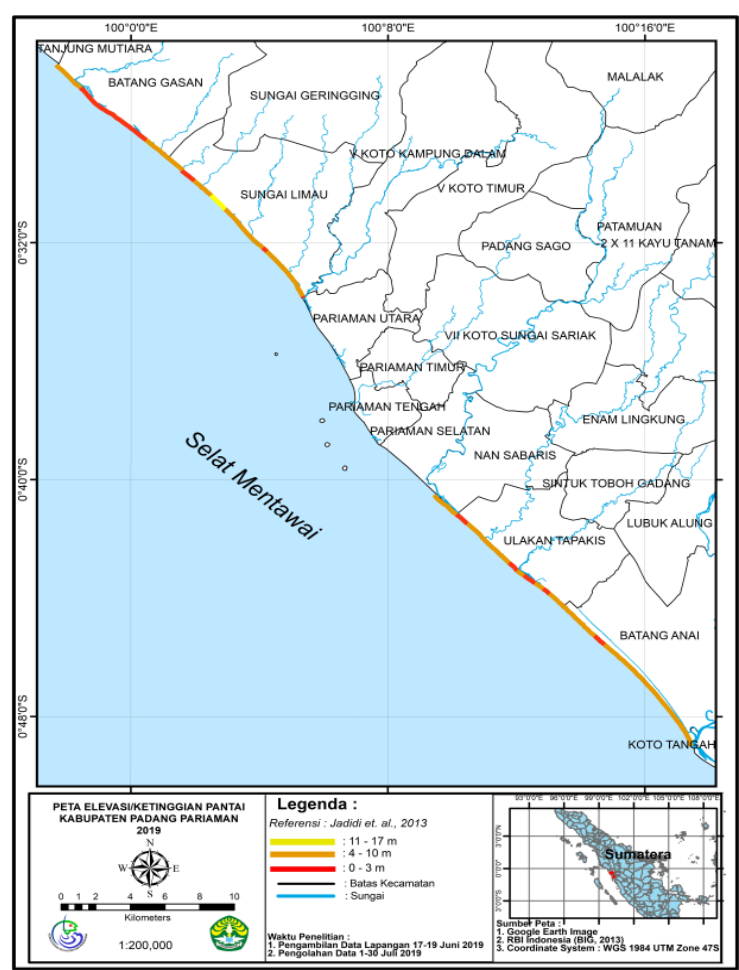

Gambar 1. Peta elevasi pantai

Pesisir Kabupaten Padang Pariaman terpapar terhadap gelombang baik itu terpapar sepenuh nya, atau terpapar sebagian. Pada beberapa kawasan terlindung sebagian oleh gelombang. Pesisir yang terpapar langsung oleh gelombang memilki kerentanan yang sangat tinggi karena akan sangat mudah mengalami erosi (Gambar 2).

Pesisir Padang Pariaman memiliki kemiringan sangat rendah yaitu berkisar antara $5-22^{\circ}$ atau $1-13 \%$. Kemiringan yang rendah mengindikasikan energi gelombang di daerah ini cukup rendah, karena kemiringan lereng pantai berbanding lurus dengan energi gelombang. Tinggi gelombang signifikan di pesisir Kabupaten Padang Pariaman berkisar antara 0,5-1m.

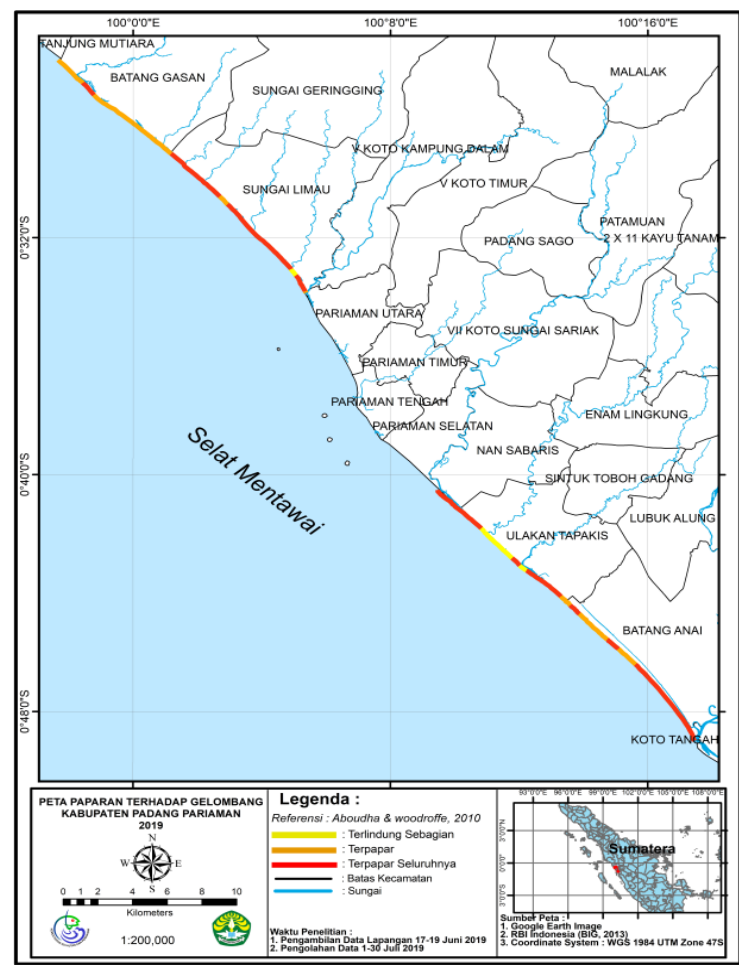

Gambar 2. Peta paparan terhadap gelombang

Abdillah dan Ramdhan (2012) menyatakan tinggi gelombang di pesisir pariaman berkisar antara 0,1-1 $\mathrm{m}$ dan gelombang yang dominan adalah gelombang arah barat.

Tunggang pasut Kabupaten Padang Pariaman sebesar 1,352 $\mathrm{m}$ dan termasuk kedalam kategori rendah (1-1,9 m) (Gambar 3). Perhitungan admiralty 15 hari diperoleh nilai bilangan Formzal (F) Padang Pariaman adalah $\mathrm{F}=1,3504$. Nilai ini menunjukan bahwa tipe pasang surut campuran condong harian ganda (mixed mainly semidiurnal tides), artinya dalam satu hari terjadi dua kali air pasang dan dua kali air surut, tetapi tinggi dan periodenya berbeda. 
Sumber : Prediksi pasut Badan Informasi Geospasial(BIG)

Grafik Pasut (m)

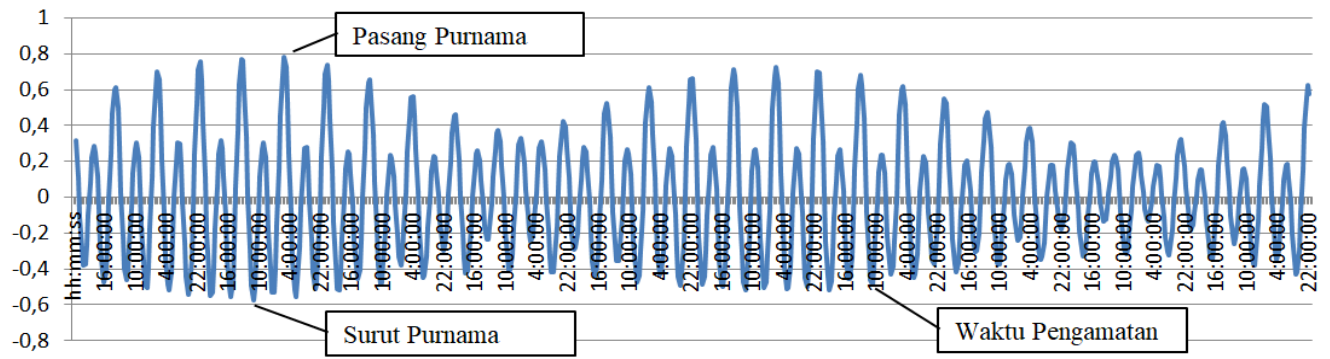

Gambar 3. Grafik prediksi pasang surut 30 hari (Juli 2019)

Fitur berm adalah kawasan yang berada di belakang pantai. Fitur berm Kabupaten Padang Pariaman adalah hutan, daerah pedesaan, urban dan mixed urban. Berdasarkan hasil pengumpulan data 50,9\% fitur berm Kabupaten Padang Pariaman adalah hutan, $30,54 \%$ daerah pedesaan dan sisanya terbagi atas urban dan mixed urban. Mixed urban memiliki nilai kerentanan sangat tinggi dan terdapat pada kecamatan ulakan tapakis (Gambar 4).

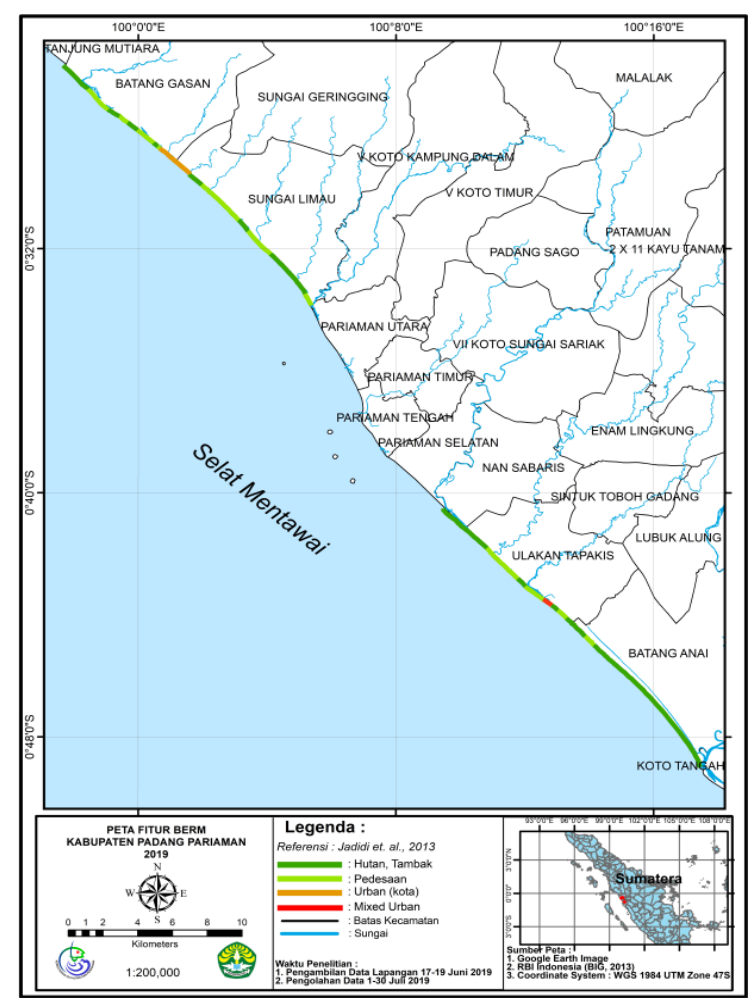

Gambar 4. Peta fitur berm

Fitur beachface Kabupaten Padang Pariaman secara keseluruhan berupa lahan
Jarak antara garis pantai dengan objek yang rentan di pesisir Kabupaten Padang Pariaman terbagi kedalam 5 kelas kerentanan yaitu sangat rendah $(>60 \mathrm{~m})$, rendah (31-60 $\mathrm{m})$, sedang(21-30 $\mathrm{m})$, tinggi (11-20 $\mathrm{m})$ dan sangat tinggi $(0-10 \mathrm{~m})$. Nilai kerentanan sangat rendah sampai sedang mendominasi di pesisir kabupaten ini, sedangkan untuk kerentanan tingi dan sangat tinggi ditemukan pada beberapa titik (Gambar 5).

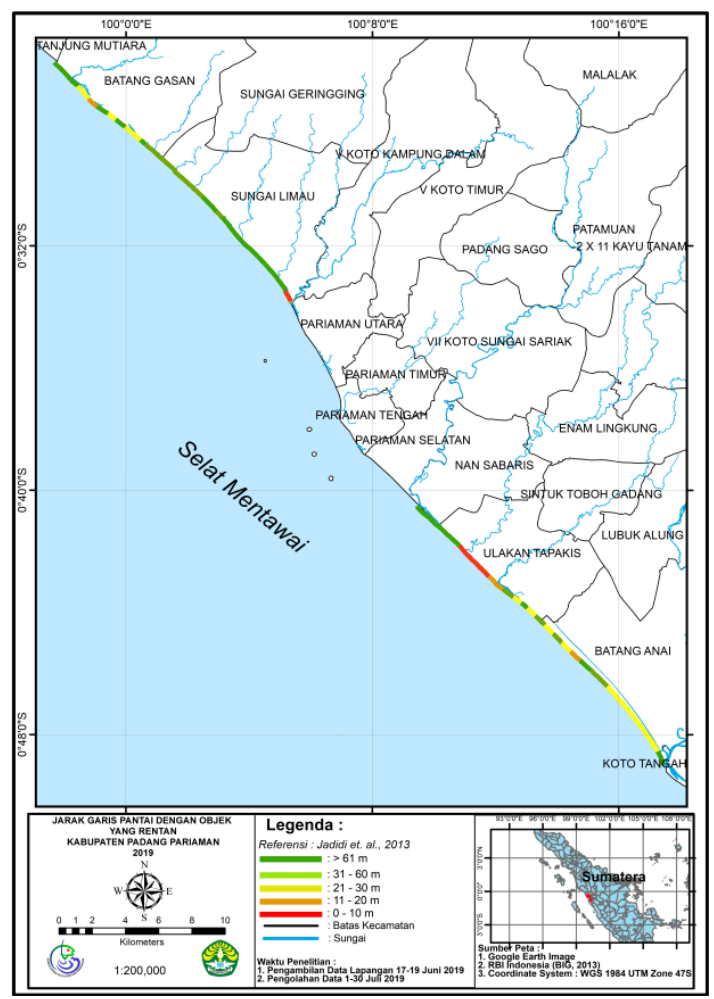

Gambar 5. Peta jarak garis pantai dengan objek yang rentan

kosong. Terdapat pelindung pantai pada beberapa bagian dan sabuk hijau tidak 
ditemukan pada pesisir pantai yang menyebabkan pantai akan terpapar langsung oleh gelombang. Pelindung pantai yang ditemukan berupa jetty dan dalam kondisi baik (Gambar 7).

Perubahan garis pantai Kabupaten

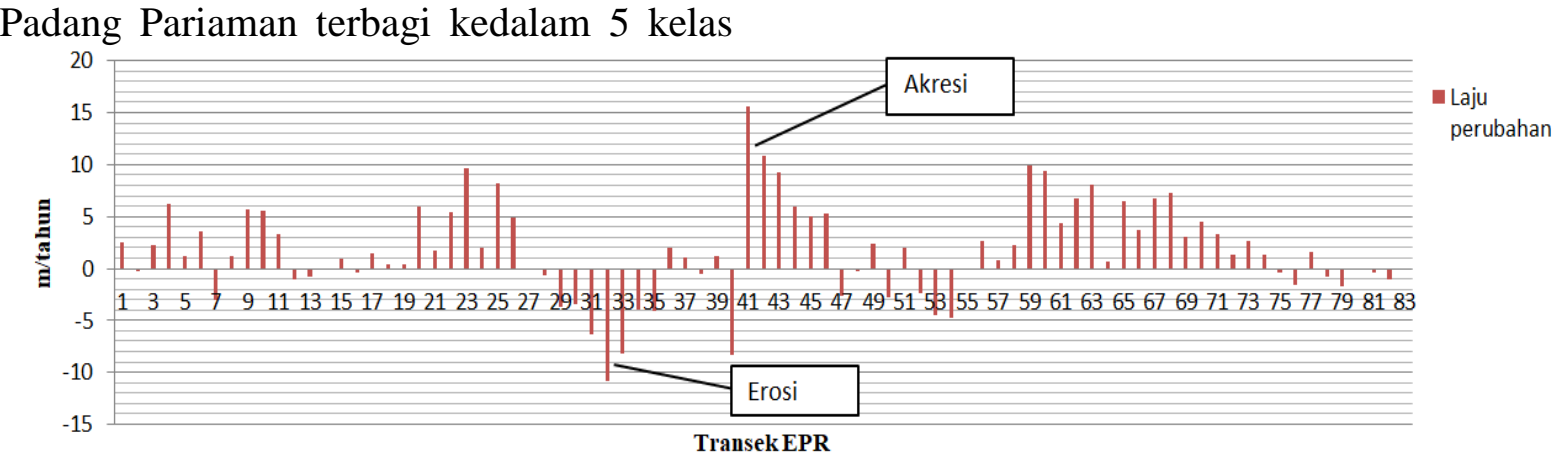

Gambar 6. Grafik laju perubahan garis pantai

Grafik laju perubahan garis pantai Kabupaten Padang Pariaman lebih dominan mengalami akresi pantai dengan laju akresi

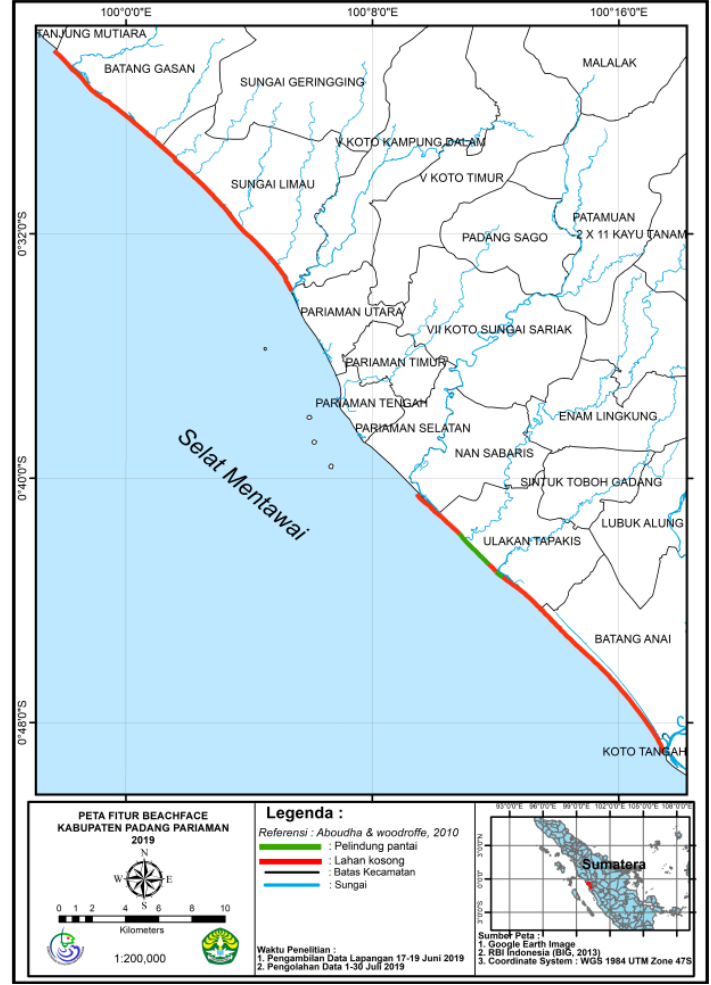

Gambar 7. Peta fitur beach face

Tata guna lahan di pesisir kabupaten ini terdiri dari Lahan kosong (Unclaimed), Pemukiman (Settlement), Industrial dan Agriculture (Gambar 9). Tata guna lahan yaitu akresi tinggi (>2,1 m/tahun), akresi rendah (1-2 $\mathrm{m} /$ tahun), $\operatorname{stabil}(-1 \quad-$ $+1) \mathrm{m} /$ tahun, erosi sedang ( $-1-2 \mathrm{~m} /$ tahun) dan erosi tinggi (<-2,1 m/tahun) (Gambar 8).

tertinggi yaitu $15,62 \mathrm{~m} /$ tahun dan laju erosi tertinggi yaitu 10,85 m/tahun (Gambar 6).

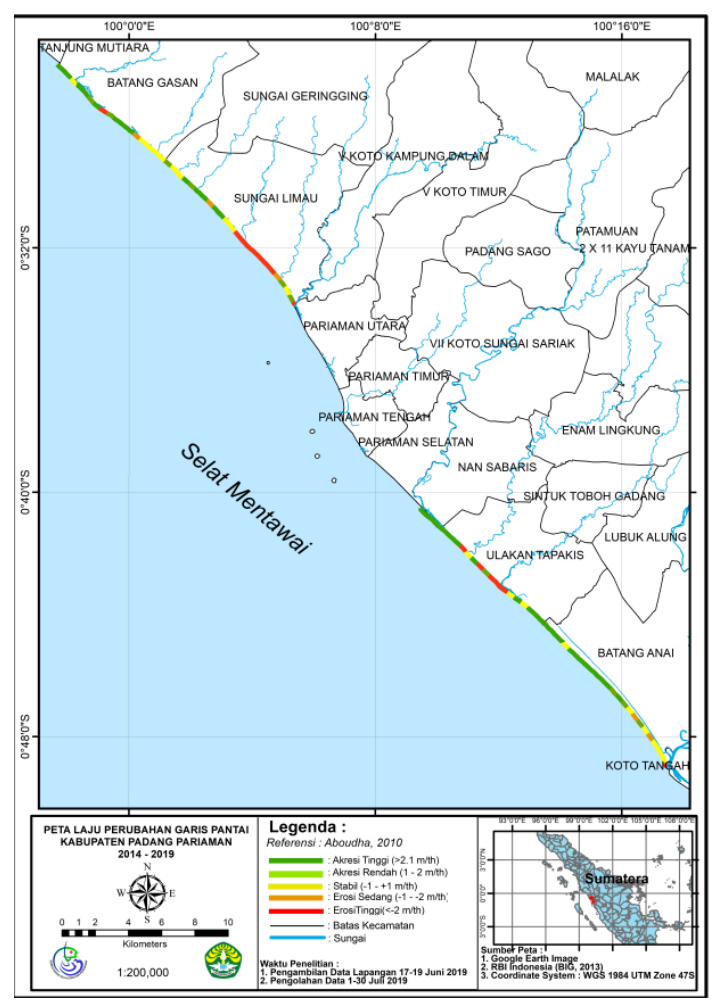

Gambar 8. Peta laju perubahan garis pantai (2014-2019)

Kabupaten Padang Pariaman tersebar secara merata namun pada kecamatan batang anai terdapat pemanfaatan lahan berupa tambak udang (agriculture) yang 
mendominasi garis pantai terseburt, dan dalam penilaian kerentanan pesisir

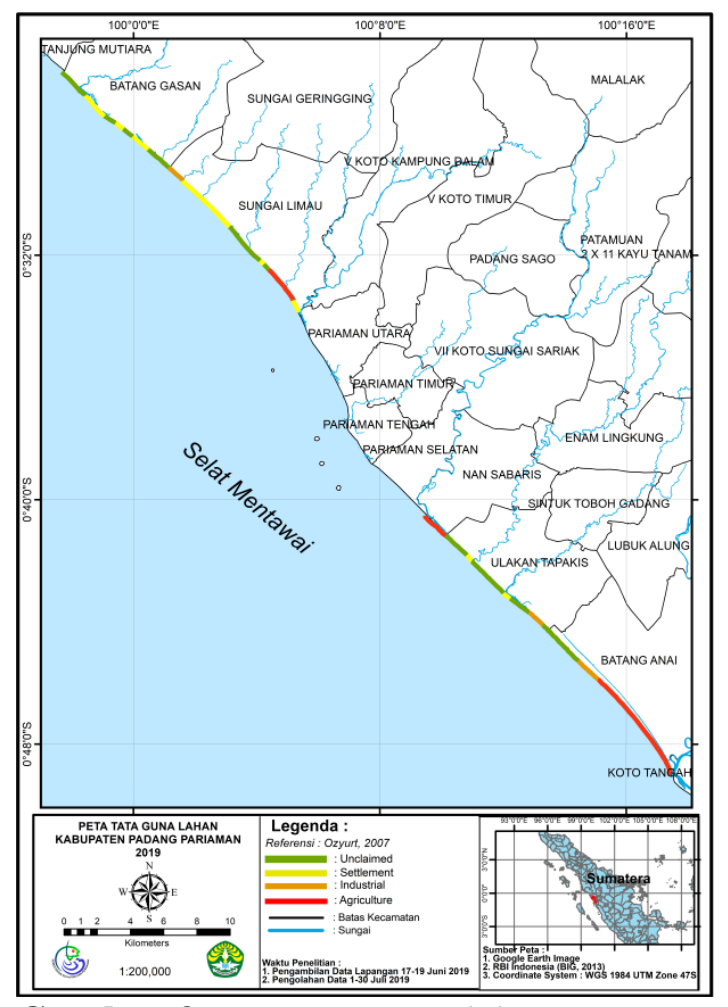

Gambar 9. Peta tata guna lahan

Indeks kerentanan pesisir Kabupaten Padang Pariaman dihitung dengan rumus CVI menggunakan 14 variabel fisik pesisir. Hasil perhitungan menunjukan nilai kerentanan pesisir Kabupaten Padang Pariaman berkisar antara 75,894 - 979,79 untuk 50 titik pengamatan. Nilai CVI yang diperoleh kemudian dikelompokan kedalam 5 kelas kerentanan sebagai berikut :

- Sangat Rendah $: \leq 195,95$

- Rendah $\quad: 195,95<\mathrm{CVI} \leq 391,91$ termasuk kedalam kategori sangat rentan.

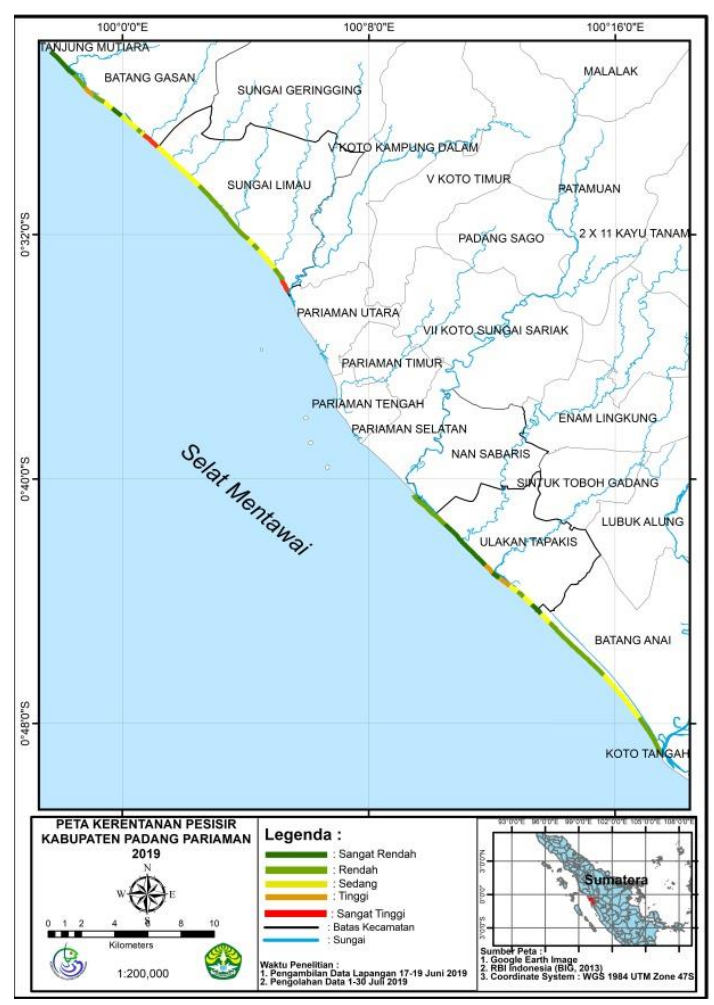

Gambar 10. Peta kerentanan pesisir

- Sedang

$: 391,91<\mathrm{CVI} \leq 587,87$

- Tinggi

: $587,87<\mathrm{CVI} \leq 783,83$

- Sangat Tinggi : $>783,83$

Nilai CVI yang telah dikelompokkan tersebut kemudian dinterpretasikan, sehingga dihasilkan sebuah peta yang memuat informasi mengenai status kerentanan pesisir Kabupaten Padang Pariaman.

Tabel 3. Panjang dan persentase kerentanan pesisir kabupaten padang pariaman

\begin{tabular}{llllllllll}
\hline \multicolumn{2}{l}{ Sangat Rendah } & Rendah & \multicolumn{3}{c}{ Sedang } & \multicolumn{2}{c}{ Tinggi } & \multicolumn{3}{l}{ Sangat Tinggi } \\
\hline $\begin{array}{l}\text { Panjang } \\
(\mathrm{m})\end{array}$ & $\%$ & $\begin{array}{l}\text { Panjang } \\
(\mathrm{m})\end{array}$ & $\%$ & $\begin{array}{l}\text { Panjang } \\
(\mathrm{m})\end{array}$ & $\%$ & $\begin{array}{l}\text { Panjang } \\
(\mathrm{m})\end{array}$ & $\%$ & $\begin{array}{l}\text { Panjang } \\
(\mathrm{m})\end{array}$ & $\%$ \\
7321,97 & 17,27 & 16564,70 & 39,08 & 12300,83 & 29,02 & 3762,44 & 8,88 & 2435,72 & 5,75 \\
\hline
\end{tabular}

Hasil perhitungan CVI menunjukan $17,27 \%$ pesisir padang pariaman memiliki kerentanan sangat rendah, 39,08\% kerentanan rendah, $29,02 \%$ kerentanan sedang, 8,88\% kerentanan tinggi dan 5,75\% kerentanan sangat tinggi (Tabel 3).

Nilai kerentanan yang sedang, tinggi dan sangat tinggi dipengaruhi oleh tidak adanya bangunan pelindung pantai yang 
menyebabkan pantai tersebut terpapar langsung oleh gelombang, geomorfologi pantai yang berupa beach, dan material penyusun pantai yang berupa soft sedimen sehingga mudah terbawa oleh arus dan gelombang. Faktor lain yang mempengaruhi adalah tinggi nya laju erosi pantai pada beberapa titik dalam kurun waktu 5 tahun terakhir. Kerentanan sedang sampai sangat tinggi banyak ditemukan pada kawasan yang terdapat pemukiman penduduk yang cukup dekat dengan garis pantai (Gambar 10).
Pesisir dengan kerentanan sangat rendah dan rendah juga ditemukan pada beberapa titik di 5 Kecamatan. Kerentanan rendah banyak ditemukan pada kawasan pesisir yang belum diolah oleh manusia atau masih berstatus unclaimed. Fitur berm pada kawasan ini berupa hutan. Pada kawasan ini laju perubahan garis pantai cendrung kearah akresi. Faktor tersebut menyebabkan nilai kerentanan menjadi rendah (Gambar 10).

\section{DAFTAR PUSTAKA}

1. Abdillah, Y., dan M. Ramdhan. (2012). Pemetaan Tingkat Kerentanan Pesisir Wilayah Kota Pariaman. Jurnal Fakultas Perikanan dan Ilmu Kelautan, Pages 128148.

2. Aboudha, P.A.O., and C.D. Woodroffe. (2010). Assessing Vulnerability to Sea-Level Rise Using a Coastal Sensitivity index: a Case Study from Shouteast Australia. Journal of coastal conservation. Volume 14, Pages 189-205.

3. Baransano, H.K. Mangimbulude. J.C. (2011). Eksploitasi Dan Konservasi Sumberdaya Hayati Laut dan Pesisir di Indonesia. Jurnal biologi papua, Volume 3(1), Pages 39-45.

4. BNPB. [Badan Nasional Penanggulangan Bencana]. (2013). Resiko Bencana Indonesia. BNPB.

5. Gornitz, V. (1991). Vulnerability Of The Us To Future Sea Level Rise. Oak Ridge National Lab. TN (USA).

6. Haryani. (2018). Kajian Perubahan Garis Pantai Provinsi Sumatera Barat. Tataloka, Volume 21(2).

7. Jadidi, A. (2013). Using Geospatial Business Intelligence Paradigm to Design a Multidimentional Conceptual Model for Efficient Coastal Erosion Risk Assessment. Journal of coastal conservation. Volume 17, Pages 527-543.

8. Kumar, T.S. (2010). Coastal Vulnerability Assessment For Orissa State, East Coast of India. Journal of coastal research. Volume 26(2), Pages 523-534.

9. Sharples, C. R. Mount, and Pedersen. (2009). The Australian Coastal Smartline Geomorphic and Stability Map Version 1: Project Report. Prepared for Geoscience Australia and the Department for Climate Change by of Geography and Environmental Studies, University of Tasmania, Hobart.

10. Thieler, E.R. (2009). Digital Shoreline Analysis System (DSAS) Version 4.0-An ArcGis extension for calculating shoreline change: U.S. Geological Survey Open-File Report 2008-1278. 